\title{
Thermal, pressure and wind fields at ground level in the area of the Italian base at Terra Nova Bay, Victoria Land, Antarctica, as observed by a network of automatic weather stations
}

\author{
E. Cogliani, G. Abbate, S. Racalbuto \\ ENEA, Italian National Agency for Energy, Technology and the Environment, c.r.e. Casaccia, via Anguillarese 301, 00100 Rome, Italy
}

Received: 23 August 1995/Revised: 13 May 1996/Accepted: 15 May 1996

\begin{abstract}
Ground temperature, pressure and wind speed monthly averages in the area of the Italian Station at Terra Nova Bay, Antarctica, were analyzed for the period 1987-1991 by means of a network of nine AWS (automatic weather stations). Spatial configurations of temperature show a well-defined, relatively warm island in the area of Terra Nova Bay, between Drygalsky and Campbell ice tongues, throughout the year. A second warm island is present to the north along the coast, between Aviator and Mariner ice tongues, for most of the year. From February to March a rapid drop in temperature is observed at all stations. A strong thermal gradient develops during February, March, April and October, November, December, between the coastal region and inner highlands. The baric configuration follows the elevation of the area. Annual average pressure and temperature as functions of stations altitude show linear trends. Severe katabatic wind episodes are recorded at all stations, with wind speed exceeding $25 \mathrm{~m} \mathrm{~s}^{-1}$ and direction following the orographic features of the inner areas. Co-occurrences of these episodes were observed for stations located along stream lines of cold air drainage. The autocorrelation function of maximum wind speed time series shows wind persistence of 2-3 days and wind periodicity of about one week.
\end{abstract}

\section{Introduction}

Meteorological data from automatic weather stations (AWS) in the area of the Antarctic Italian Base at Terra Nova Bay, Victoria Land, have been collected since 1985 (Pellegrini and Marucci, 1989; Bromwich, 1990). A network of AWS was progressively established in co-ordination with USA Programme at McMurdo Station (Bromwich, 1990; Bromwich and Pellegrini, 1990). Clima-

Correspondence to: E. Cogliani tology analyses have been conducted in the area (Baldi et al., 1990; Cogliani et al., 1992; Del Buono et al., 1992; Grigioni et al., 1992). As the area is situated along the coast and due to the particular terrain, it is relatively warmer than surrounding areas. Remarkable climatic features of Terra Nova Bay are the occurrence of strong katabatic winds and the presence of a stable polynya (water area free of ice), which is of particular importance, as considerable energy exchanges take place between ocean and atmosphere. Mesoscale cyclogenesis in the area of Terra Nova Bay was studied statistically, using AWS data in combination with digital satellite imagery (Carrasco and Bromwich, 1993, 1994). It was found that in the region adjacent to Terra Nova Bay, the formation of mesoscale vortices is very frequent. Model studies have shown that a confluence zone is present in the area, where the surface winds from the interior of the continent converge (Parish and Bromwich, 1987). Thus, katabatic winds can be very strong and persistent, in agreement with observations (Parish and Bromwich, 1989; Bromwich and Pellegrini, 1990). Katabatic winds and mesocyclonic activity have been simulated by mesoscale models (Gallée and Schayes, 1994; Gallée, 1995). It has been demonstrated that katabatic winds result in the formation of mesocyclones in the coastal areas of Victoria Land.

Italian AWS coordinates and altitude are given in Table 1, together with the year and month of installation/availability of data. Figure 1 shows AWS locations on a sketch map of Victoria Land, including the coast line and the main glaciers. Data are used for meteorological assistance to the operations at the Antarctic Station and transmitted to ENEA Casaccia research centre via the NOAA polar orbiting meteorological satellites and the ARGOS processing centre in Toulouse (France), for scientific research purposes (Cogliani et al., 1992). An Oracle data base allows easy access, archive, management and visualization of data. Since 1987, three-hourly observations of the following meteorological parameters have been available: wind direction (degrees), wind speed $\left(\mathrm{m} \mathrm{s}^{-1}\right)$, maximum wind speed $\left(\mathrm{m} \mathrm{s}^{-1}\right)$, air temperature 
Table 1. Italian AWS (automatic weather stations) in Antarctica

\begin{tabular}{|c|c|c|c|c|}
\hline $\begin{array}{l}\text { AWS ID No. (name) } \\
\text { Site }\end{array}$ & $\begin{array}{l}\text { Height } \\
\text { (m) }\end{array}$ & Latitude & Longitude & Data availability from \\
\hline $\begin{array}{l}7350 \text { Sofia } \\
\text { Nansen ice sheet }\end{array}$ & 55 & $74^{\circ} 47^{\prime} 45^{\prime \prime} \mathrm{S}$ & $163^{\circ} 18^{\prime} 46^{\prime \prime} \mathrm{E}$ & February 1987 \\
\hline $\begin{array}{l}7351 \text { Alessandra } \\
\text { Cape King }\end{array}$ & 183 & $73^{\circ} 35^{\prime} 10^{\prime \prime} \mathrm{S}$ & $166^{\circ} 37^{\prime} 16^{\prime \prime} \mathrm{E}$ & February 1987 \\
\hline $\begin{array}{l}7352 \text { Zoraida } \\
\text { Priestley Glacier }\end{array}$ & 640 & $74^{\circ} 15^{\prime} 14^{\prime \prime} \mathrm{S}$ & $163^{\circ} 08^{\prime} 41^{\prime \prime} \mathrm{E}$ & February 1987 \\
\hline $\begin{array}{l}7353 \text { Eneide } \\
\text { Italian Base }\end{array}$ & 80 & $74^{\circ} 41^{\prime} 42^{\prime \prime} \mathrm{S}$ & $164^{\circ} 05^{\prime} 36^{\prime \prime} \mathrm{E}$ & February 1987 \\
\hline $\begin{array}{l}7354 \text { Chiara } \\
\text { Eliport }\end{array}$ & 20 & $74^{\circ} 41^{\prime} 42^{\prime \prime} \mathrm{S}$ & $164^{\circ} 07^{\prime} 23^{\prime \prime} \mathrm{E}$ & January 1989 \\
\hline $\begin{array}{l}7355 \text { Modesta } \\
\text { Priestley source }\end{array}$ & 1930 & $73^{\circ} 38^{\prime} 18^{\prime \prime} \mathrm{S}$ & $160^{\circ} 38^{\prime} 35^{\prime \prime} \mathrm{E}$ & February 1989 \\
\hline $\begin{array}{l}7356 \text { Lola } \\
\text { Tourmaline Plateau }\end{array}$ & 1700 & $74^{\circ} 10^{\prime} 59^{\prime \prime} \mathrm{S}$ & $163^{\circ} 29^{\prime} 00^{\prime \prime} \mathrm{E}$ & January 1990 \\
\hline $\begin{array}{l}7357 \text { Arelis } \\
\text { Cape Ross }\end{array}$ & 200 & $76^{\circ} 43^{\prime} 56^{\prime \prime} \mathrm{S}$ & $163^{\circ} 00^{\prime} 35^{\prime \prime} \mathrm{E}$ & January 1990 \\
\hline $\begin{array}{l}7379 \text { Silvia } \\
\text { Cape Philips }\end{array}$ & 200 & $73^{\circ} 04^{\prime} 21^{\prime \prime} \mathrm{S}$ & $169^{\circ} 06^{\prime} 55^{\prime \prime} \mathrm{E}$ & December 1990 \\
\hline
\end{tabular}

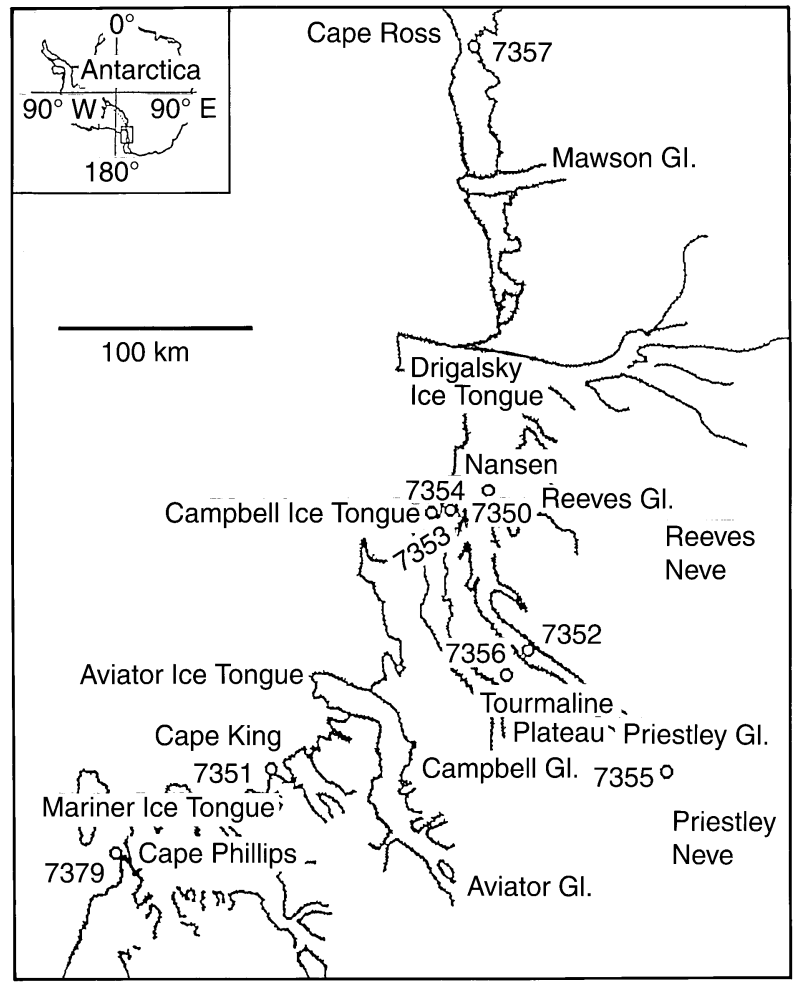

Fig. 1. Sketch map of Victoria Land and AWS locations

$\left({ }^{\circ} \mathrm{C}\right)$, minimum temperature $\left({ }^{\circ} \mathrm{C}\right)$, maximum temperature $\left({ }^{\circ} \mathrm{C}\right)$, dew point temperature $\left({ }^{\circ} \mathrm{C}\right)$, atmospheric pressure $(\mathrm{hPa})$, barometric trend $(\mathrm{hPa})$, average solar radiation $\left(\mathrm{W} / \mathrm{m}^{2}\right)$, maximum solar radiation $\left(\mathrm{W} / \mathrm{m}^{2}\right)$. Previous works on Italian AWS data were based on statistical analysis of available data, mostly aimed at describing katabatic wind characteristics (Bromwich and Pellegrini, 1990; Cogliani et al., 1992; Del Buono et al., 1992; Grigioni et al., 1992; Pellegrini and Marucci, 1989). In the present study, all data collected for the period 1987-1991 have been used to determine the main characteristics of mean 5 -year patterns of temperature, pressure and wind speed in the area. Three-hourly monthly averages and standard deviations of temperature, pressure and wind speed were computed and tabled. Thermal and wind speed fields were also isocontoured on the map for visual intercomparison. Dates of occurrence of wind speed $>25 \mathrm{~m} / \mathrm{s}$ were then represented graphically, to give an overview for all stations and the complete data set. Autocorrelation function of maximum wind speed 3-hourly data time-series was computed to study wind persistence and wind periodicity. Further details on Antarctic climatology are illustrated in Schwerdtfeger (1984), Cogliani et al. (1992), Périard and Pettré (1993).

\section{Data analysis and results}

Table 2 shows monthly average temperature values, standard deviations and the number of cases on which average values were computed. Some values are missing due to insufficient availability of measurements: January data for stations 7354 and 7379; June, July, August, September data for station 7356. A clear seasonal behaviour for temperature is observed. The warmest months are January and December, the coldest are May, June, July and August. Temperature values also show a clear dependence on the altitude of the station. Accordingly, the coldest station is the one at highest altitude (station 7355, $1930 \mathrm{~m}$ a.s.1.). From February to March a rapid drop in temperature is observed at all stations, coinciding with sun elevation and 
Table 2. Monthly average temperature $\left({ }^{\circ} \mathrm{C}\right)$, standard deviation and number of cases at all AWS

\begin{tabular}{|c|c|c|c|c|c|c|c|c|c|}
\hline & AWS 73 & & & AWS 73 & & & AWS 7 & & \\
\hline & $T$ & $\sigma$ & $c$ & $T$ & $\sigma$ & $c$ & $T$ & $\sigma$ & $c$ \\
\hline Jan & -4.7 & 2.9 & 984 & -2.6 & 1.8 & 867 & -8.0 & 2.4 & 973 \\
\hline $\mathrm{Feb}$ & -10.9 & 4.0 & 1096 & -7.0 & 2.6 & 912 & -14.3 & 4.1 & 1081 \\
\hline Mar & -19.5 & 4.6 & 1228 & -14.6 & 3.9 & 1141 & -22.8 & 4.6 & 1160 \\
\hline Apr & -23.2 & 5.9 & 1085 & -18.2 & 5.5 & 973 & -26.0 & 5.5 & 948 \\
\hline May & -26.0 & 6.0 & 807 & -20.6 & 5.9 & 718 & -28.6 & 4.8 & 756 \\
\hline Jun & -26.4 & 6.9 & 771 & -20.2 & 6.0 & 498 & -29.9 & 6.4 & 725 \\
\hline Jul & -24.4 & 5.8 & 813 & -20.7 & 5.1 & 538 & -27.1 & 6.1 & 767 \\
\hline Aug & -25.9 & 6.8 & 853 & -21.4 & 6.5 & 621 & -30.1 & 6.2 & 792 \\
\hline Sep & -23.7 & 6.0 & 1046 & -20.0 & 5.8 & 926 & -27.1 & 5.6 & 997 \\
\hline Oct & -18.6 & 4.9 & 1197 & -15.9 & 4.4 & 943 & -22.0 & 4.6 & 1002 \\
\hline Nov & -11.2 & 5.1 & 1195 & -9.1 & 4.4 & 876 & -14.6 & 5.0 & 941 \\
\hline Dec & -4.1 & 2.8 & 1149 & -2.5 & 2.3 & 1101 & -7.3 & 2.4 & 1182 \\
\hline & AWS 73 & & & AWS 73 & & & AWS 7 & & \\
\hline & $T$ & $\sigma$ & $c$ & $T$ & $\sigma$ & $c$ & $T$ & $\sigma$ & $c$ \\
\hline Jan & -1.6 & 1.8 & 787 & & & & -21.0 & 4.0 & 338 \\
\hline Feb & -6.3 & 3.0 & 924 & -3.5 & 3.4 & 321 & -27.8 & 6.0 & 316 \\
\hline Mar & -14.2 & 4.2 & 1150 & -13.5 & 5.2 & 351 & -37.2 & 6.5 & 459 \\
\hline $\mathrm{Apr}$ & -17.4 & 5.8 & 1067 & -16.3 & 5.9 & 381 & -39.7 & 6.1 & 342 \\
\hline May & -20.2 & 5.4 & 852 & -14.0 & 8.7 & 386 & -41.0 & 4.9 & 400 \\
\hline Jun & -21.1 & 5.8 & 775 & -15.5 & 8.2 & 353 & -40.2 & 7.1 & 321 \\
\hline Jul & -19.8 & 5.2 & 781 & -16.0 & 8.6 & 389 & -38.2 & 8.6 & 389 \\
\hline Aug & -21.0 & 6.3 & 855 & -15.5 & 8.3 & 354 & -41.6 & 5.3 & 272 \\
\hline Sep & -19.1 & 5.6 & 1009 & -16.0 & 7.6 & 355 & -40.5 & 4.4 & 319 \\
\hline Oct & -14.5 & 4.1 & 1196 & -14.2 & 4.2 & 404 & -36.8 & 5.8 & 466 \\
\hline Nov & -7.8 & 4.5 & 1170 & -5.6 & 4.6 & 234 & -28.0 & 7.0 & 538 \\
\hline Dec & -1.2 & 2.2 & 1212 & -1.7 & 4.4 & 427 & -18.7 & 3.7 & 686 \\
\hline & AWS 73 & & & AWS 73 & & & AWS 7 & & \\
\hline & $T$ & $\sigma$ & $c$ & $T$ & $\sigma$ & $c$ & $T$ & $\sigma$ & $c$ \\
\hline Jan & -12.0 & 5.0 & 432 & -2.7 & 2.1 & 247 & & & \\
\hline Feb & -16.8 & 3.0 & 426 & -7.1 & 3.0 & 366 & -7.9 & 1.5 & 223 \\
\hline Mar & -22.6 & 4.1 & 349 & -16.0 & 4.6 & 493 & -15.5 & 4.8 & 246 \\
\hline Apr & -24.8 & 5.0 & 364 & -19.3 & 4.8 & 478 & -18.9 & 4.1 & 236 \\
\hline May & -24.9 & 5.0 & 233 & -22.4 & 6.3 & 486 & -23.1 & 5.8 & 235 \\
\hline Jun & & & & -21.2 & 5.4 & 466 & -19.9 & 4.8 & 223 \\
\hline Jul & & & & -23.7 & 4.8 & 483 & -23.9 & 4.8 & 243 \\
\hline Aug & & & & -25.5 & 5.4 & 488 & -22.8 & 5.0 & 211 \\
\hline Sep & & & & -23.0 & 5.9 & 472 & -20.9 & 5.0 & 212 \\
\hline Oct & -21.7 & 6.4 & 65 & -17.5 & 3.9 & 493 & -18.4 & 3.6 & 204 \\
\hline Nov & -16.3 & 6.5 & 397 & -8.7 & 4.7 & 475 & -11.7 & 3.3 & 193 \\
\hline Dec & -10.7 & 6.0 & 165 & -1.7 & 3.1 & 484 & -5.4 & 2.1 & 187 \\
\hline
\end{tabular}

sunset, varying from a minimum of about $6^{\circ} \mathrm{C}$ at station 7356 to a maximum of about $10^{\circ} \mathrm{C}$ at stations 7354 and 7355. Minimum values of average temperature are observed in June at Stations 7350 and 7353, in July at Station 7379 and 7354, in August at Station 7351, 7352, 7355, 7357; at Station 7354 the minimum temperature value is observed also in September. A small increase in temperature can be noticed at all stations in June or July. A rapid rise in temperature (around $8-10^{\circ} \mathrm{C}$ ) is observed from September to October. Temperature continues rising also in November (around $6-7^{\circ} \mathrm{C}$ ), and reaches its top values in December and January. Isotherms have been plotted on the sketch map. Note that stations 7353 and 7354 are almost coincident, at the Base site. Figures 2 and
3 show thermal fields for February and July, as examples exhibiting typical features. Spatial configurations of monthly average temperature show a well-defined, relatively warm island in close to Terra Nova Bay, between Drygalsky and Campbell ice tongues, throughout the year due to the presence of a stable polynya. All coastal stations show higher temperature than those inland due to the vicinity of the ocean. A strong thermal gradient is present for the whole year between the coastal region and the inner highlands. The weakest thermal gradients, and consequently the lowest wind speed values, are observed in December and January (Cogliani et al., 1992; Périard and Pettré, 1993) when the ocean is more ice-free. During summer, in fact, inner area temperatures are closer to sea 


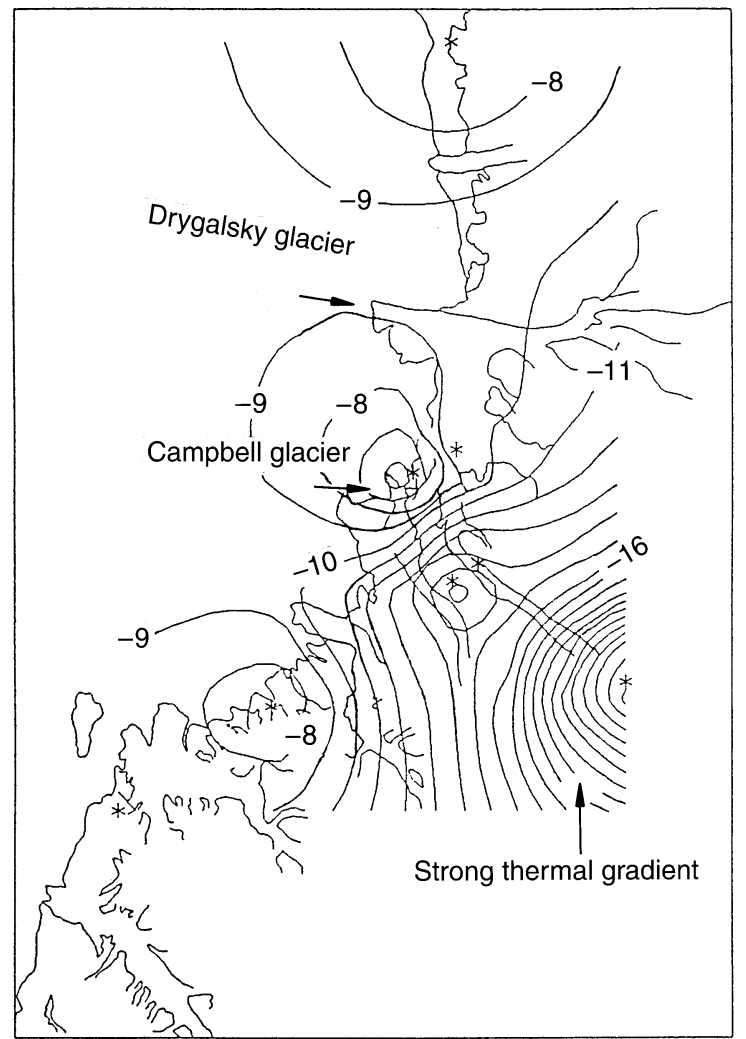

Fig. 2. Monthly average temperature isolines $\left({ }^{\circ} \mathrm{C}\right)$, February

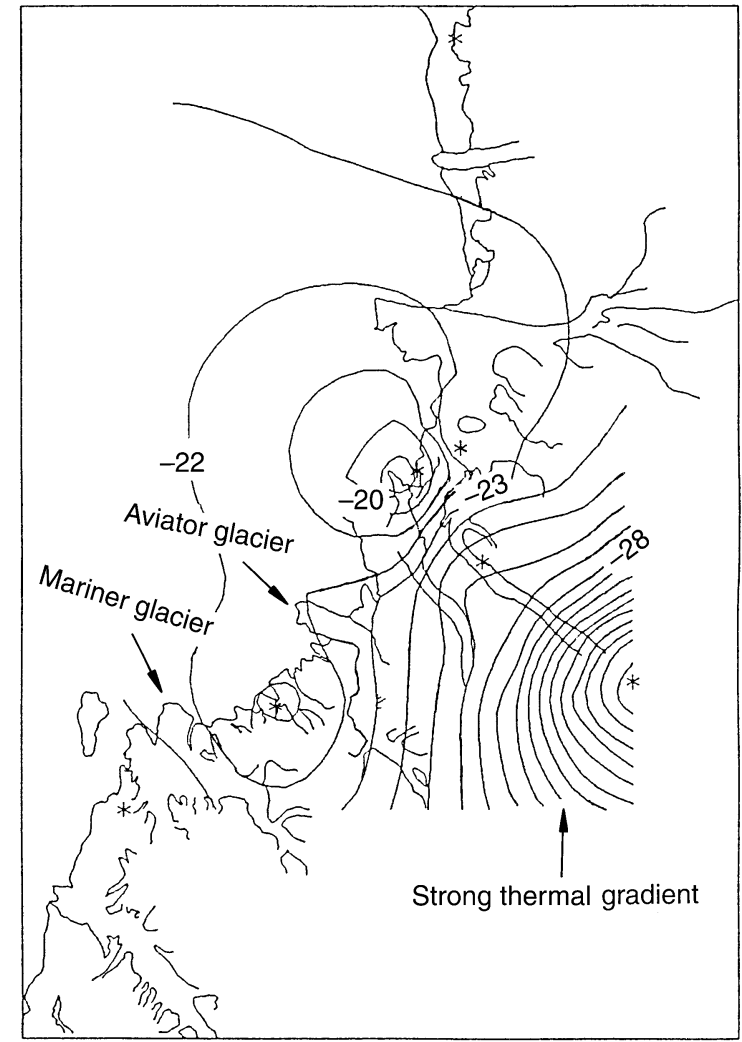

Fig. 3. Monthly average temperature isolines $\left({ }^{\circ} \mathrm{C}\right)$, July

Table 3. Monthly average pressure (hPa), standard deviation and number of cases at all AWS

\begin{tabular}{|c|c|c|c|c|c|c|c|c|c|}
\hline & \multicolumn{3}{|c|}{ AWS 7350} & \multicolumn{3}{|c|}{ AWS 7351} & \multicolumn{3}{|c|}{ AWS 7352} \\
\hline & $P$ & $\sigma$ & $c$ & $P$ & $\sigma$ & $c$ & $P$ & $\sigma$ & $c$ \\
\hline Jan & 985.6 & 6.5 & 988 & 972.5 & 6.2 & 871 & 913.6 & 6.5 & 851 \\
\hline Feb & 985.1 & 7.8 & 1096 & 971.2 & 7.9 & 912 & 912.1 & 7.2 & 1081 \\
\hline Mar & 985.1 & 7.2 & 1228 & 970.8 & 7.1 & 1141 & 910.0 & 6.1 & 1120 \\
\hline $\mathrm{Apr}$ & 989.7 & 10.2 & 1006 & 975.7 & 8.6 & 973 & 914.7 & 10.3 & 825 \\
\hline May & 987.8 & 14.2 & 805 & 976.8 & 10.9 & 718 & 911.1 & 13.6 & 756 \\
\hline Jun & 988.2 & 8.3 & 771 & 976.3 & 7.6 & 498 & 911.2 & 7.7 & 725 \\
\hline Jul & 989.7 & 11.6 & 813 & 977.9 & 10.2 & 538 & 913.5 & 10.7 & 787 \\
\hline Aug & 983.6 & 10.1 & 852 & 969.2 & 10.1 & 621 & 907.2 & 9.2 & 792 \\
\hline Sep & 983.3 & 12.6 & 1046 & 969.1 & 12.7 & 926 & 905.6 & 11.6 & 817 \\
\hline Oct & 981.2 & 11.4 & 1197 & 969.3 & 10.4 & 943 & 910.1 & 10.4 & 754 \\
\hline Nov & 980.7 & 7.5 & 1196 & 966.2 & 7.0 & 878 & 907.9 & 7.3 & 703 \\
\hline \multirow[t]{3}{*}{ Dec } & 986.2 & 6.8 & 1152 & 973.7 & 6.6 & 1105 & 915.2 & 7.2 & 935 \\
\hline & \multicolumn{3}{|c|}{ AWS 7353} & \multicolumn{3}{|c|}{ AWS 7354} & \multicolumn{3}{|c|}{ AWS 7355} \\
\hline & $P$ & $\sigma$ & $c$ & $P$ & $\sigma$ & $c$ & $P$ & $\sigma$ & $c$ \\
\hline Jan & 980.9 & 6.9 & 791 & & & & 769.5 & 6.6 & 338 \\
\hline Feb & 979.6 & 8.3 & 924 & 988.5 & 7.5 & 321 & 769.1 & 6.7 & 316 \\
\hline Mar & 979.1 & 7.5 & 1150 & 986.4 & 6.3 & 351 & 763.1 & 6.4 & 464 \\
\hline Apr & 983.4 & 9.9 & 1067 & 993.0 & 10.4 & 381 & 768.8 & 9.6 & 346 \\
\hline May & 982.1 & 14.1 & 852 & 995.0 & 12.1 & 386 & 767.0 & 12.9 & 426 \\
\hline Jun & 982.1 & 8.2 & 775 & 993.3 & 7.3 & 353 & 766.9 & 8.3 & 331 \\
\hline Jul & 983.8 & 11.6 & 781 & 997.1 & 8.5 & 389 & 769.8 & 9.6 & 464 \\
\hline Aug & 976.9 & 11.9 & 854 & 985.8 & 10.3 & 353 & 761.0 & 6.4 & 304 \\
\hline Sep & 976.6 & 12.6 & 1010 & 982.5 & 11.3 & 355 & 758.5 & 10.4 & 341 \\
\hline Oct & 975.6 & 11.3 & 1196 & 982.0 & 13.1 & 404 & 758.8 & 11.4 & 466 \\
\hline Nov & 975.5 & 7.7 & 1176 & 986.1 & 8.5 & 234 & 767.2 & 7.8 & 538 \\
\hline Dec & 982.1 & 7.0 & 1222 & 991.9 & 7.7 & 428 & 772.6 & 6.2 & 686 \\
\hline
\end{tabular}


Table 3. Continued

\begin{tabular}{|c|c|c|c|c|c|c|c|c|c|}
\hline & \multicolumn{3}{|c|}{ AWS 7356} & \multicolumn{3}{|c|}{ AWS 7357} & \multicolumn{3}{|c|}{ AWS 7379} \\
\hline & $P$ & $\sigma$ & $c$ & $P$ & $\sigma$ & $c$ & $P$ & $\sigma$ & $c$ \\
\hline Jan & 803.2 & 9.0 & 384 & 969.8 & 5.4 & 247 & & & \\
\hline Feb & 800.9 & 6.4 & 426 & 975.5 & 6.1 & 366 & 927.4 & 5.5 & 223 \\
\hline Mar & 794.6 & 6.4 & 349 & 972.0 & 7.3 & 493 & 918.2 & 6.3 & 246 \\
\hline Apr & 798.9 & 9.7 & 364 & 978.7 & 11.9 & 478 & 924.4 & 7.4 & 236 \\
\hline May & 806.2 & 12.3 & 233 & 981.7 & 13.4 & 486 & 921.1 & 10.6 & 235 \\
\hline Jun & & & & 977.9 & 7.2 & 466 & 924.5 & 8.8 & 223 \\
\hline Jul & & & & 983.3 & 9.6 & 483 & 925.8 & 8.2 & 243 \\
\hline Aug & & & & 971.1 & 8.5 & 488 & 918.9 & 8.0 & 210 \\
\hline Sep & & & & 965.4 & 11.4 & 472 & 917.6 & 12.3 & 211 \\
\hline Oct & 774.7 & 29.3 & 65 & 968.6 & 12.8 & 493 & 915.5 & 15.1 & 204 \\
\hline Nov & 791.3 & 23.2 & 401 & 972.8 & 6.9 & 476 & 922.3 & 8.7 & 193 \\
\hline Dec & 807.3 & 4.6 & 149 & 978.2 & 7.0 & 487 & 931.0 & 4.7 & 187 \\
\hline
\end{tabular}

Table 4. Monthly average wind speed $\left(\mathrm{m} \mathrm{s}^{-1}\right)$, standard deviation and number of cases at all AWS

\begin{tabular}{|c|c|c|c|c|c|c|c|c|c|}
\hline & \multicolumn{3}{|c|}{ AWS 7350} & \multicolumn{3}{|c|}{ AWS 7351} & \multicolumn{3}{|c|}{ AWS 7352} \\
\hline & $S$ & $\sigma$ & $c$ & $S$ & $\sigma$ & $c$ & $S$ & $\sigma$ & $c$ \\
\hline Jan & 4.4 & 4.0 & 988 & 2.1 & 2.8 & 871 & 9.0 & 5.9 & 972 \\
\hline Feb & 6.3 & 5.5 & 1096 & 2.0 & 2.6 & 912 & 11.9 & 6.7 & 1081 \\
\hline Mar & 8.2 & 7.0 & 1228 & 1.6 & 2.1 & 1141 & 14.6 & 7.4 & 1160 \\
\hline Apr & 7.5 & 6.9 & 1085 & 1.8 & 2.5 & 972 & 15.7 & 7.3 & 948 \\
\hline May & 6.8 & 6.0 & 807 & 2.1 & 2.6 & 718 & 14.6 & 6.6 & 756 \\
\hline Jun & 7.2 & 6.5 & 771 & 3.5 & 5.2 & 498 & 16.4 & 7.2 & 725 \\
\hline Jul & 7.6 & 7.5 & 813 & 2.2 & 2.8 & 536 & 16.7 & 8.7 & 787 \\
\hline Aug & 9.5 & 8.5 & 853 & 2.7 & 3.7 & 621 & 19.7 & 8.8 & 792 \\
\hline Sep & 8.2 & 7.8 & 1046 & 2.6 & 3.5 & 926 & 17.5 & 8.2 & 997 \\
\hline Oct & 6.4 & 5.9 & 1196 & 2.4 & 3.5 & 943 & 14.1 & 8.2 & 1002 \\
\hline Nov & 5.6 & 5.0 & 1196 & 2.4 & 3.2 & 878 & 10.2 & 6.1 & 939 \\
\hline \multirow[t]{3}{*}{ Dec } & 3.8 & 3.4 & 1152 & 2.8 & 3.7 & 1106 & 7.4 & 5.0 & 1182 \\
\hline & \multicolumn{3}{|c|}{ AWS 7353} & \multicolumn{3}{|c|}{ AWS 7354} & \multicolumn{3}{|c|}{ AWS 7355} \\
\hline & $S$ & $\sigma$ & $c$ & $S$ & $\sigma$ & $c$ & $S$ & $\sigma$ & $c$ \\
\hline Jan & 3.9 & 4.2 & 791 & & & & 4.4 & 2.9 & 338 \\
\hline Feb & 6.4 & 5.7 & 924 & 3.7 & 2.4 & 321 & 5.5 & 2.9 & 316 \\
\hline Mar & 8.0 & 6.4 & 904 & 4.4 & 3.1 & 351 & 8.1 & 2.7 & 464 \\
\hline Apr & 6.9 & 7.8 & 912 & 3.8 & 3.5 & 381 & 7.8 & 2.9 & 346 \\
\hline May & 6.1 & 5.9 & 610 & 2.6 & 2.0 & 386 & 7.2 & 2.5 & 426 \\
\hline Jun & 6.8 & 7.3 & 540 & 3.5 & 3.3 & 353 & 5.4 & 4.2 & 326 \\
\hline Jul & 6.6 & 7.3 & 543 & 2.7 & 2.5 & 389 & 7.5 & 3.4 & 464 \\
\hline Aug & 7.5 & 7.2 & 614 & 3.7 & 3.2 & 354 & 7.0 & 3.7 & 303 \\
\hline Sep & 8.6 & 8.4 & 627 & 3.5 & 3.5 & 355 & 7.8 & 3.3 & 351 \\
\hline Oct & 4.2 & 5.7 & 949 & 2.2 & 1.9 & 404 & 7.5 & 2.8 & 466 \\
\hline Nov & 5.2 & 5.6 & 937 & 3.7 & 2.7 & 234 & 5.8 & 2.6 & 546 \\
\hline \multirow[t]{3}{*}{ Dec } & 4.2 & 4.1 & 979 & 3.3 & 1.9 & 428 & 4.5 & 2.4 & 686 \\
\hline & \multicolumn{3}{|c|}{ AWS 7356} & \multicolumn{3}{|c|}{ AWS 7357} & \multicolumn{3}{|c|}{ AWS 7379} \\
\hline & $S$ & $\sigma$ & $c$ & $S$ & $\sigma$ & $c$ & $S$ & $\sigma$ & $c$ \\
\hline Jan & 3.4 & 3.5 & 432 & 4.1 & 2.9 & 247 & & & \\
\hline Feb & 4.3 & 3.9 & 426 & 6.6 & 3.8 & 366 & 8.5 & 6.0 & 223 \\
\hline Mar & 5.1 & 5.1 & 349 & 7.8 & 3.9 & 493 & 8.5 & 7.0 & 246 \\
\hline Apr & 6.1 & 7.3 & 364 & 6.6 & 4.9 & 478 & 7.3 & 5.8 & 236 \\
\hline May & 3.7 & 3.7 & 233 & 5.4 & 4.3 & 486 & 11.6 & 10.5 & 235 \\
\hline Jun & & & & 6.9 & 5.2 & 466 & 11.4 & 11.8 & 223 \\
\hline Jul & & & & 5.4 & 4.7 & 483 & 11.8 & 11.1 & 243 \\
\hline Aug & & & & 6.3 & 5.0 & 488 & 11.1 & 9.5 & 211 \\
\hline Sep & & & & 7.7 & 5.8 & 472 & 11.7 & 10.9 & 212 \\
\hline Oct & 0.1 & 0.2 & 64 & 5.6 & 4.2 & 493 & 11.1 & 10.1 & 204 \\
\hline Nov & 3.1 & 5.3 & 391 & 4.8 & 3.3 & 473 & 10.0 & 8.7 & 193 \\
\hline Dec & 2.9 & 3.4 & 165 & 5.0 & 3.3 & 487 & 11.5 & 9.4 & 187 \\
\hline
\end{tabular}

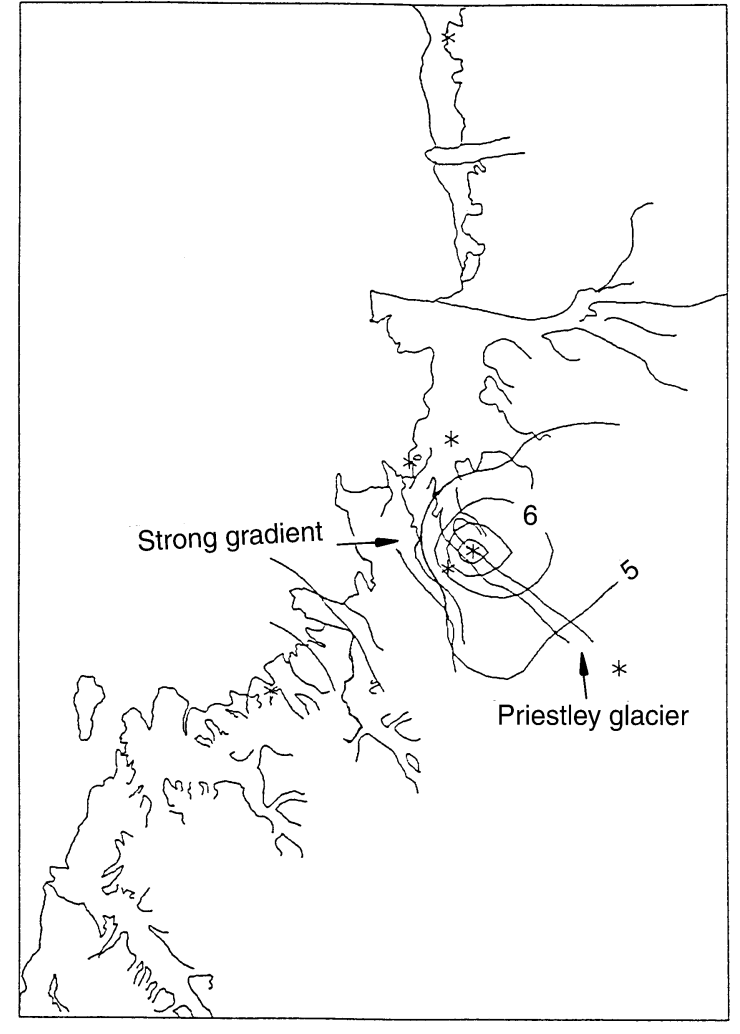

Fig. 4. Monthly average wind speed isolines $(\mathrm{m} / \mathrm{s})$, January

temperatures, due to intense solar radiation and ocean heat storage capacity, while winter temperatures at highaltitude inner areas are much lower than sea-ice temperatures. The relation between annual temperature averages $\left({ }^{\circ} \mathrm{C}\right)$ and height $(\mathrm{m})$ is linear; the best fit is:

$T(h)=-0.0071 * h-14.4339$

It can be observed that temperature gradient is greater than the normal lapse rate at middle latitudes $\left(=0.0065^{\circ} \mathrm{C} / \mathrm{m}\right)$. To this purpose, it should be noticed that the lapse rate was reconstructed from observations at ground level, where air is close to ice or frozen soil and thus cold and dense, rather than from data in the free 


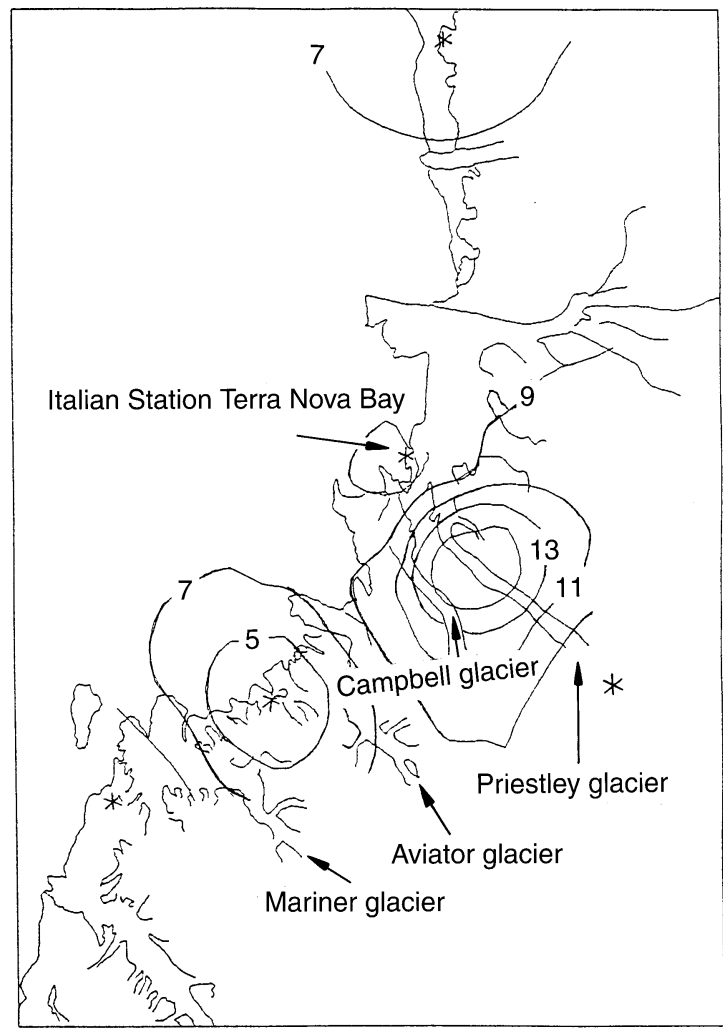

Fig. 5. Monthly average wind speed isolines (m/s), August

atmosphere. Data from radiosoundings and remote sensing will have to be included in the analysis. Table 3 shows monthly average pressure values, standard deviations and the number of cases from which average values were computed. June, July, August and September values for station 7356 are missing, due to insufficient availability of measurements. The constantly lower pressures at station 7379 are due to insufficient accuracy in the altitude and/or pressure measurements. A linear relation holds between annual pressure averages $(\mathrm{hPa})$ and height $(\mathrm{m})$; the best fit is:

$p(h)=-0.1126 * h+984.6794$
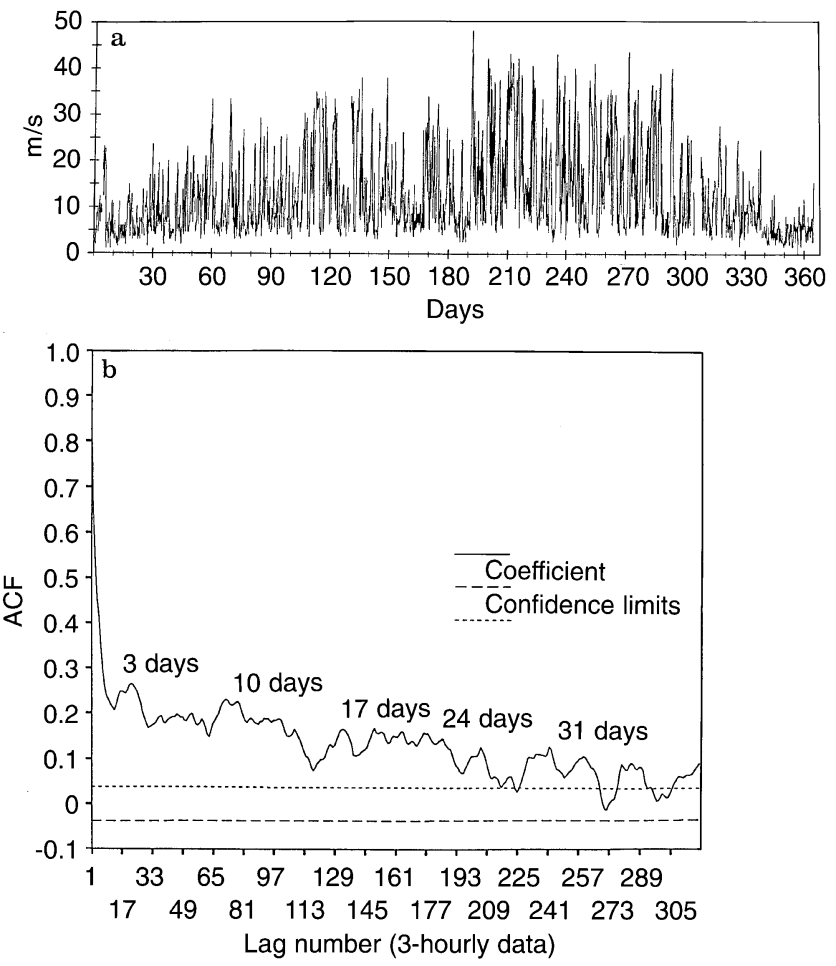

Fig. 7. a Maximum wind speed, AWS 7350, year 1989 (3-hourly data), b Maximum wind speed normalized autocor relation function, AWS 7350, year 1989 (3-hourly data)

Table 4 shows monthly average wind speed values, standard deviations and the number of cases from which average values were computed. It can be observed that the windiest months are June, July, August and September while the less windy months are December and January and that the windiest stations are 7379 and 7352 . Isocontours of monthly average wind speed are given in Figs. 4 and 5 for, respectively, January and August, as examples exhibiting typical features. A strong wind speed gradient is observed at Priestley Glacier (station 7352) the whole year. Due to wind channeling by the Priestley Glacier, this location is much windier than other stations. The strongest wind intensities and gradients are observed in August.

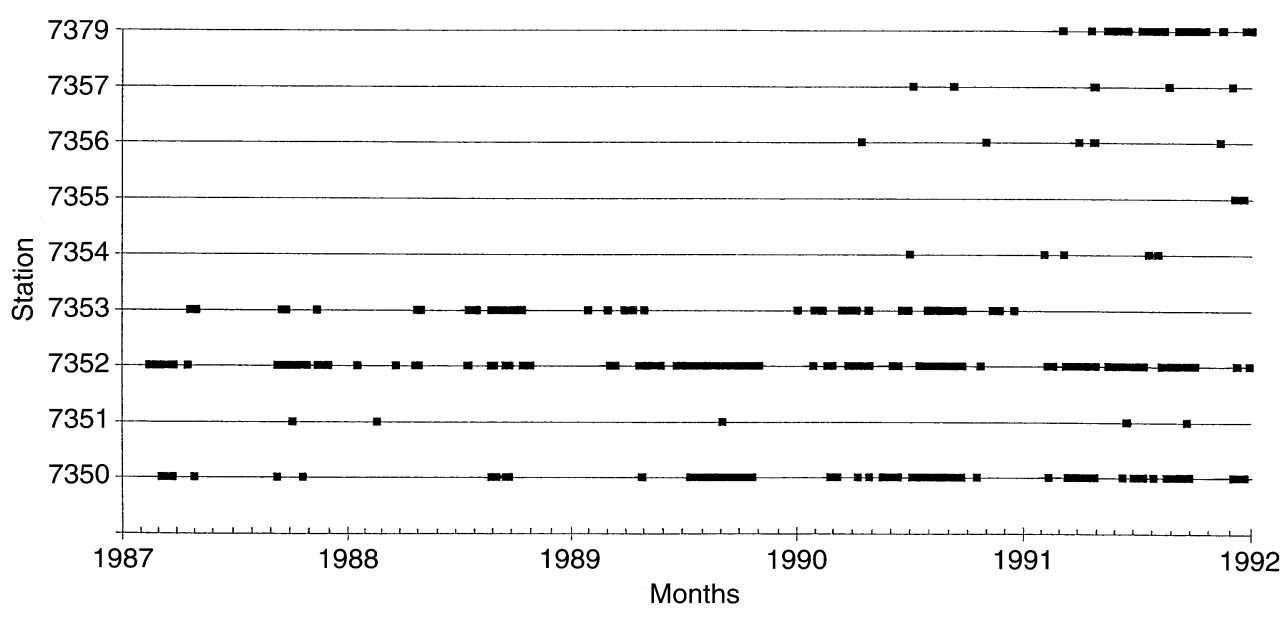

Fig. 6. Occurrence of severe wind conditions (wind speed $>25 \mathrm{~m} \mathrm{~s}^{-1}$ ) 
Episodes of katabatic wind, speed exceeding $25 \mathrm{~m} \mathrm{~s}^{-1}$ and direction following the orographic features of the inner areas, are recorded (Bromwich and Pellegrini, 1990; Cogliani et al., 1992; Del Buono et al., 1992). Occurrence/nonoccurrence cases for all stations are shown in Fig. 6. Data availability is shown in Table 1 . It can be observed that severe wind episodes occur almost at the same time at stations 7350, 7352 and 7353, which are along the same stream lines of cold air drainage from the Antarctic plateau (Parish and Bromwich, 1991). Figure 7 shows: (a) maximum wind speed 3-hourly values for station 7350 , year 1989, as an example, and (b) the corresponding normalized autocorrelation functions. The maximum wind speed time-series exhibits a typical annual sinusoidal behaviour; autocorrelation function shows a wind persistence of 2-3 days and a wind periodicity of about one week. As katabatic winds are due to periodic drainage of cold air which slowly accumulates on the Antarctic plateau, a detailed analysis of large-scale pressure fields would be very useful to understand this behaviour. This requires data from a much wider set of stations.

\section{Conclusions}

Data acquired by nine AWS in the period 1987-1991 have been exploited to describe the monthly mean temperature, pressure and wind speed patterns of the region surrounding the Italian Antarctic Base. Temperature, pressure and wind speed characteristics as deduced from our data are in good agreement with results reported in literature (Bromwich, 1989; Parish and Bromwich, 1989, 1991; Carrasco and Bromwich, 1993). The area of Terra Nova Bay is at the centre of a relatively warm island, favourable for the installation of a permanent base. A peculiar effect of cyclonic activity in the area was observed: the slight increase in average temperature observed in June or July also at non coastal stations. Driven by strong and persistent katabatic drainage, boundary layer baroclinic zones are formed when cold continental air invades warmer maritime air. These baroclinic zones are considered to be the major cause of cyclogenesis in Victoria land. Our data show that they extend rather far inland (station 7355, in July). The normal vertical temperature gradient was found to be $-0.0071^{\circ} \mathrm{C} / \mathrm{m}$, that is greater than that at middle latitudes $\left(=0.0065^{\circ} \mathrm{C} / \mathrm{m}\right)$, as expected due to greater density of atmosphere at the Poles. The weakest thermal gradients between inland and coastal areas and, consequently, the lowest wind speed values were observed in December and January, that is summer season and smaller sea-ice extension. For severe wind episodes typical wind persistence of 2-3 days and wind periodicities of about one week were inferred. Further work will be aimed at explaining the physical significance of these periodicities by analyzing large-scale pressure fields. Single events of katabatic and non-katabatic flow will be analyzed in more detail. Temperature and pressure relations with height will be derived for these two types of events. Data from other sources, such as radiosoundings and remote sensing will be included in the analysis.
Acknowledgements. This study was supported by the Italian Scientific Project for Research in Antarctica. The authors wish to thank Dr. John Muthama (University of Nairobi, on leave at the University of Roma "La Sapienza", Department of Physics) for helpful discussions.

The Editor in Chief thanks P. Pettre and another referee for their help in evaluating this paper.

\section{References}

Baldi, M., A. Di Menno, A. Guerrini, A. Anav, M. Di Menno, and C. Valenti, Climatology analysis in the boundary layer at Terra Nova Bay, Antarctica, Conference Proceedings "Italian Research on Antarctic Atmosphere,', Eds. M. Colacino, G. Giovanelli, L. Stefanutti, 27, SIF, Bologna, 121-140, 1990.

Bromwich, D. H., Subsynoptic-scale cyclone development in the Ross sea sector of the Antarctic, in Polar and Arctic lows, Eds. P. F. Twitchell, E. A. Rasmussen, K. L. Davidson, ISBN 0937194-19-0, 331-345, 1989.

Bromwich, D. H., International cooperative studies of the Antarctic planetary boundary layer, Conference Proceedings "Italian Research on Antarctic Atmosphere,', Eds. M. Colacino, G. Giovanelli, L. Stefanutti, 27, SIF, Bologna, 19-25, 1990.

Bromwich, D. H., and A. Pellegrini, Katabatic wind events during the summer half-year at Tethys Bay Site, Terra Nova Bay, Conference Proceeding "Italian Research on Antarctic Atmosphere,', Eds. M. Colacino, G. Giovanelli, L. Stefanutti, 27, SIF, Bologna, 153-154, 1990.

Carrasco, J. F., and D. H. Bromwich, Mesoscale cyclogenesis dynamics over the southwestern Ross Sea, Antarctica, J. Geophys. Res., 98, 12973-12995, 1993.

Carrasco, J. F., and D. H. Bromwich, Climatological aspects of mesoscale cyclogenesis over the Ross Sea and Ross ice shelf of Antarctica, Mon. Weather Rev., 122, 2405-2425, 1994.

Cogliani, E., A. Pellegrini, and S. Racalbuto, Analysis of Antarctic data, February 1987-August 1990, Conference Proceedings "Italian Research on Antarctic Atmosphere", Eds. M. Colacino, G. Giovanelli, L. Stefanutti, 34, SIF, Bologna, 35-47, 1992.

Del Buono, P., A. M. Della Vedova, and G. Fiocco, Analysis of Antarctic boundary layer wind regimes in the neighbourhood of Terra Nova Bay, Conference Proceedings "Italian Research on Antarctic Atmosphere,', Eds. M. Colacino, G. Giovanelli, L. Stefanutti 35, SIF, Bologna, 123-135, 1992.

Gallée, H., Simulation of the mesocyclonic activity in the Ross Sea, Antarctica, Mon. Weather Rev., 123, 2051-2069, 1995.

Gallée, H., and G. Schayes, Development of a three-dimensional meso- $\gamma$ primitive equations model: katabatic winds simulation in the area of Terra Nova Bay, Antarctica, Mon. Weather Rev., 122, 671-685, 1994.

Grigioni, P., L. De Silvestri, A. Pellegrini, and R. Sarao, Some climatological aspects in the Terra Nova Bay area, Antarctica, Conference Proceedings "Italian Research on Antarctic Atmosphere,', Eds. M. Colacino, G. Giovanelli, L. Stefanutti, 35, SIF, Bologna, 97-121, 1992.

Parish, R., and D. H. Bromwich, The surface wind field over the Antarctic ice sheets, Nature, 328, 51-54, 1987.

Parish, R., and D. H. Bromwich, Instrumented aircraft observations of the katabatic wind regime near Terra Nova Bay, Mon. Weather Rev., 117(7), American Meteorological Society, pp. 1570-1585, 1989.

Parish, R., and D. H. Bromwich, Continental-scale simulation of the Antarctic katabatic wind regime, J. Clim., 4, 135-146, 1991.

Pellegrini, A., and F. Marucci, Meteorological facilities at the Italian base Terra Nova Bay Station, Conference Proceedings "Italian Research on Antarctic Atmosphere,', Eds. M. Colacino, G. Giovanelli, L. Stefanutti, 20, SIF, Bologna, 39-57, 1989.

Périard, C., and Pettré, P., Some aspects of the climatology of Dumont D'Urville, Adélie Land, Antarctica, Int. J. Climatol., 13, 313-327, 1993.

Schwerdtfeger, W., Developments in atmospheric science 15, in Weather and Climate of the Antarctic, Elsevier, Amsterdam, 1984. 